\title{
Non-Revenue Water (NRW) is a challenge for Global Water Supply System Management: A case study of Dhaka Water Supply System Management
}

\author{
G. M. G Farok* \\ York University, Toronto, Canada \\ Dhaka WASA, Bangladesh \\ *Corresponding e-mail: gazi.farok@yahoo.com
}

\begin{abstract}
Non-revenue Water (NRW) is an important component of commercial water system management. NRW is the result of pipelines leakage, improper, illegal service connections and theft water. NRW contributes system loss that is a buzzword. Actually, NRW is uncounted water that has been produced but it is confirmed to be "lost" before it consumes the customer. This matter agitates for all concern and specially it affects the whole economy. Dhaka Water Supply and Sewerage Authority (DWASA) is one of the main utilities in Dhaka City and it is the most important sector of the Government of Bangladesh. The potable water distribution network has been installed at the whole area of the city and it covers periphery of the city and its extension is going from N. Gonj to Tongi as well as surrounding area of this city. Non-revenue water surveys were conducted on specific fields and areas that were selected randomly. It would be gradually becoming a serious issue affecting the interest of all concerned and would be one of the major crises to be solved with techno-managerial concept.
\end{abstract}

Keywords: Water, Revenue, Supply, Management, Unaccounted.

\section{INTRODUCTION}

International Water Association (IWA) recommends the use of NRW. NRW is the difference between system input volume and billed authorized consumption, and it components are: unbilled authorized consumption (usually a minor component of water balance), apparent losses and real losses ${ }^{1}$. Unaccounted-for water (UFW) is often taken as a measure of the efficiency of a water supply system. In the early 1980s, Singapore's unaccounted for water was about 11 percent of total output ${ }^{2}$. Main Contributing factors to un-accounted for water are: meter inaccuracies, losses through leakage, inaccurate accounting of water used in new and existing installations, illegal draw off. NRW tends to System Loss which should be brought down to acceptable limit by elevating the revenues. The technical knowledge and logistics support should increase to achieve the goals. Employees should be healthy, honest and sincere. Restructure the organization is the claim of time. Existing compensation system and salary structures are no more effective and should be reformed immediately. It is suggested that many systems with NRW above $40 \%$ have numerous visible leaks in service connections, high rates of estimated consumptions and thousands of illegal connection that can be addressed to reduce non-revenue water. The priority should be fixing in visible leaks (technical loss) and paper leaks (administrative or commercial loss). Community based organization (CBO) on water supply, storm water drainage and sewerage can provide suggestions for preventing unauthorized connections and reducing $\mathrm{NRW}^{3}$. The governance should be improved and accomplished by promoting decentralizations, strengthening, monitoring, evaluating, elevating managerial and technical knowhow through training and development, research and learning at all levels, especially in the Operation \& Management department and revenue department with building capacity ${ }^{4}$. The most important factor to mitigate the ailment of commercial losses to very considerable proportion would be combined effort under the frame-work of close consideration between the commercial and engineering departments. Instead of blaming each other for failure to attain the required target, each department should reflect on its own performance in the accomplishment of its part of the job as a component in the inter linked effort to cumulate the revenue generation. Ground water abstracted by privately owned DTWs in Dhaka and Narayanganj city are not yet detected and actual abstractions by privately owned DTWs would be much more than that of estimated 5 .

DRINKING WATER SUPPLY SYSTEM IN DHAKA CiTY

DWASA is entrusted with supply of piped water to Dhaka Metropolitan city, DND area, Narrayanganj City Corporation in the South and Mirpur-Uttara in the North and adjacent area. As of June 2014, 75\% city area was under DWASA water supply coverage. Out of which $78.86 \%$ is from ground water sources tapping through 675 deep tube wells, the remaining $21.14 \%$ of the water is supplied from the two major treatment plant situated at Saidabad, Chadnighat and two smaller units in Narayanganj ${ }^{6}$. The population of Dhaka city presently about 12.5 million and the growth trends 
indicate that by the year 2025 it would be about 22 million. In order to meet the growing demand, DWASA is installing high capacity water wells tapping the upper Dupitalia aquifers. But this aquifer is in stressed condition and major part of the city area the ground water discharge in upper aquifer is much less compare to the abstraction, causing ground water mining. The average ground water depletion in most of the areas in the city is reportedly around 2-3 meter/year ${ }^{3}$.

\section{AQUIFER OF WATER SUPPLY SOURCES}

The present rate of depletion gives an alarming indication that there is an urgent need to alleviate pressure on the aquifer being exploited and explore for more suitable and sustainable sources to supplement the current water supply. The peripheral rivers are the only dependable surface water source but these no more considered to be a suitable source of water due to continued pollution.

There exists an alarming situation to find alternate sources for Dhaka city water supply. These probable sources may consider: the deeper aquifer (around 300-meter depth) and surface water sources from far off major rivers like Padma, Meghna and Jamuna. In addition, it is worthwhile to research on exploitable potential of aquifers located in the vicinity of Dhaka City. Demand management is an important concept for any water services in large cities around the world in order to optimize the use of scarce water resources. In Dhaka city it is imperative to develop an immediate, mid-term and long term strategy for water supply system considering domestic, commercial and industrial consumptions due to its growing population.

\section{SIGNIFICANCE OF NON-REVENUE WATER}

Non-Revenue Water is an issue familiar to the concerned people and an important policy making tool for the management. It is the difference between system input volume and billed authorized consumption, and it consists of the following: i) Unbilled water consumption, ii) apparent losses and iii) real losses. The unplanned development of Dhaka city made haphazard expansion of water distribution network under a lot of crash programs. These leaded to mismanagements in operation especially in distribution network. Approximately more than 55\% (25\% technical and $30 \%$ commercial or administration) of the total water production had been calculated as unaccounted-for water (UFW) or Non-Revenue Water (NRW) in the form of system losses during the year
2001. The identified aspects of inefficient management leading to these system losses are: i) unplanned development of distribution system, ii) delayed attendance to repair works with call center information and lack of professional and ethical execution, iii) lack of preventive maintenance, iv) malpractices of revenue collections for personal gain and other purposes, v) consumption by house owners through bypass and illegal connections, vi) Lack of coordination among waste prevention, MODS, Revenue and Meter Divisions and vii) absence of monitoring of follow-up actions.

$$
\begin{aligned}
& \text { NRW=System Input }- \text { Billed Authorized } \\
& \text { Consumption }
\end{aligned}
$$

Reducing levels of NRW can contribute to attaining Million Development Goal to reduce the proportion of people without access to safe drinking water. But the problem is global in scale, solutions need to be tailored to local circumstances due to variation in the cause of water loss and the mechanisms available to manage them. These differences in this system is a greater proportion of water loss being of a commercial nature eg. customer meter under registration, data-handling errors, theft of water etc in developing countries compared to developed countries where physical losses are by far the highest loss factor [see Fig 1].

Total Consumed of Leakage From Mains =Number Of Reported Bursts X Average Leak Flow Rate X Average Leak Occuring Duration

Total Commercial Loss $=$ NRW-NNF $($ Net Night Flow) (3)

(4)

$$
\mathrm{L} 1 / \mathrm{L} 2=\left((\mathrm{P} 1 / \mathrm{P} 2)^{\wedge} \mathrm{N}\right.
$$

Where,

$\mathrm{L}=$ Leakage Rate,

$\mathrm{P}=$ Pressure,

$\mathrm{N}=$ Number of Leakage

If $\mathrm{NNF}=0$, then $\mathrm{NRW}$ is directly calculated commercial loss and leakage is proportional to pressure but exponential to the number of increasing of leakages 


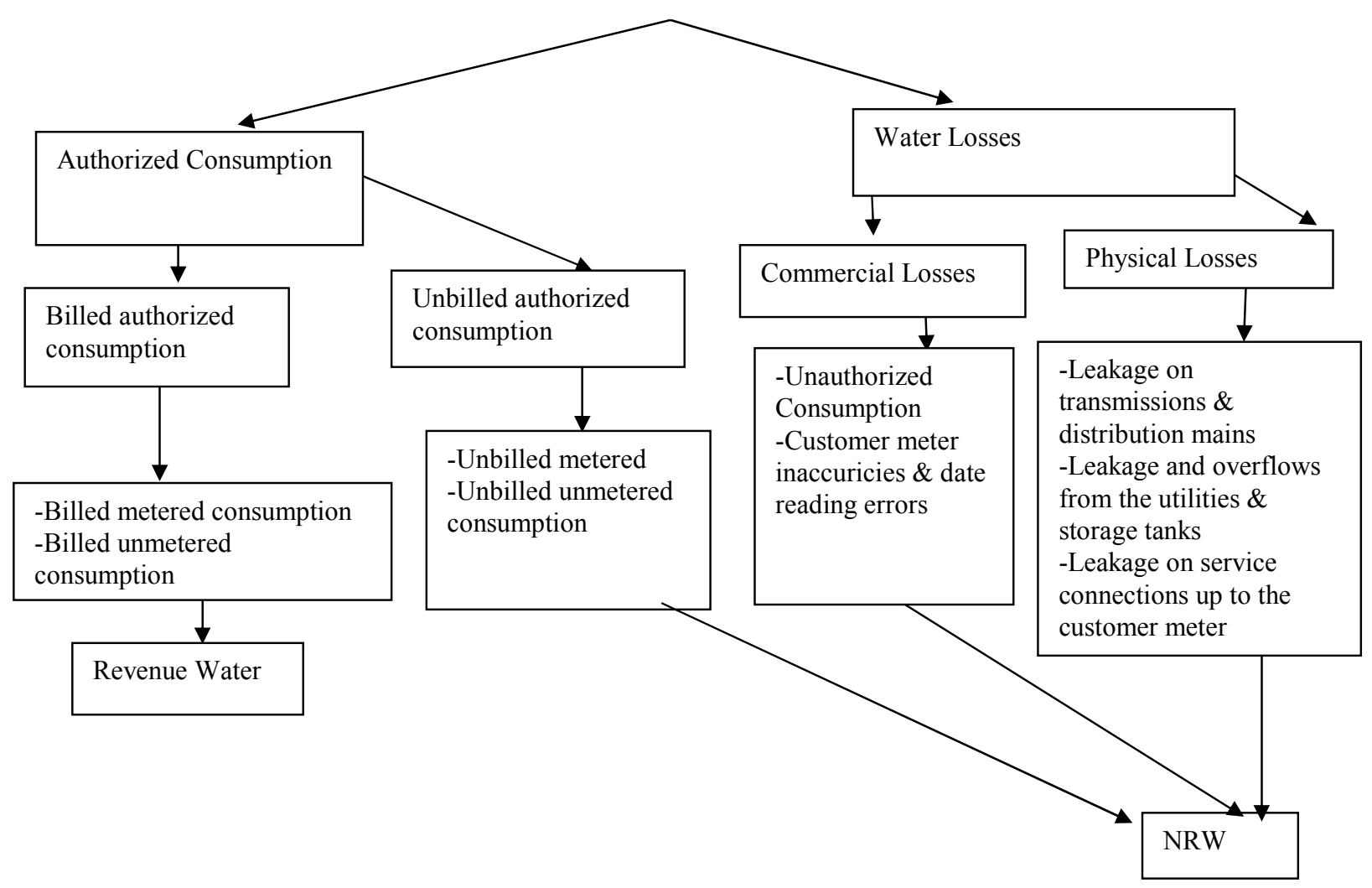

Figure 1: Steps for calculating NRW using the IWA water balance table.

\section{IMPORTANCE OF NRW}

Pure water is precious and scare substance for lives. NRW faces the challenges in solving the unsolved problem in city water supply system. It assesses the technical, financial \& management standard and proposed amelioration achievable in this regards. It unfolds and identifies the consumers those who have illegal connections have estimated actual below real consumption cheating those who pay for water. It enumerates details about service connections including storage facilities. It identifies malpractice on the service connection and associated activities and collects information on sewer connection/ septic tank. The world bank recommended that NRW should be "less than 25\%", while the Chilean water regulator SISS has determined a NRW level of $15 \%$ as optimal in its model of an efficient water company that it uses to benchmark service providers ${ }^{11}$. In England and Wales NRW stands at $19 \%$ or 149 liter/property/day ${ }^{12}$. In the United States the American Water Works
Association's (AWWA) Water Loss Control Committee recommended in 2009 that water utilities conduct annual water audits as a standard business practice. AWWA recommends that water utilities should track volumes of apparent and real losses and the annual cost impacts of these losses. Utilities should then seek to control excessive losses to levels that are economic for the water utility ${ }^{13}$. In 1999 the California Urban Water Conservation Council estimated a 10 percent benchmark for non-revenue water ${ }^{14}$.

\section{Limitations OF Ground AND SURFACE WATER SOURCES}

Groundwater supplies in aquifers below the surface of the Earth are the most important water resources all over the world. Ground water is the source of about $70 \%$ of the water used for public supply in Dhaka city [Fig 2]. 


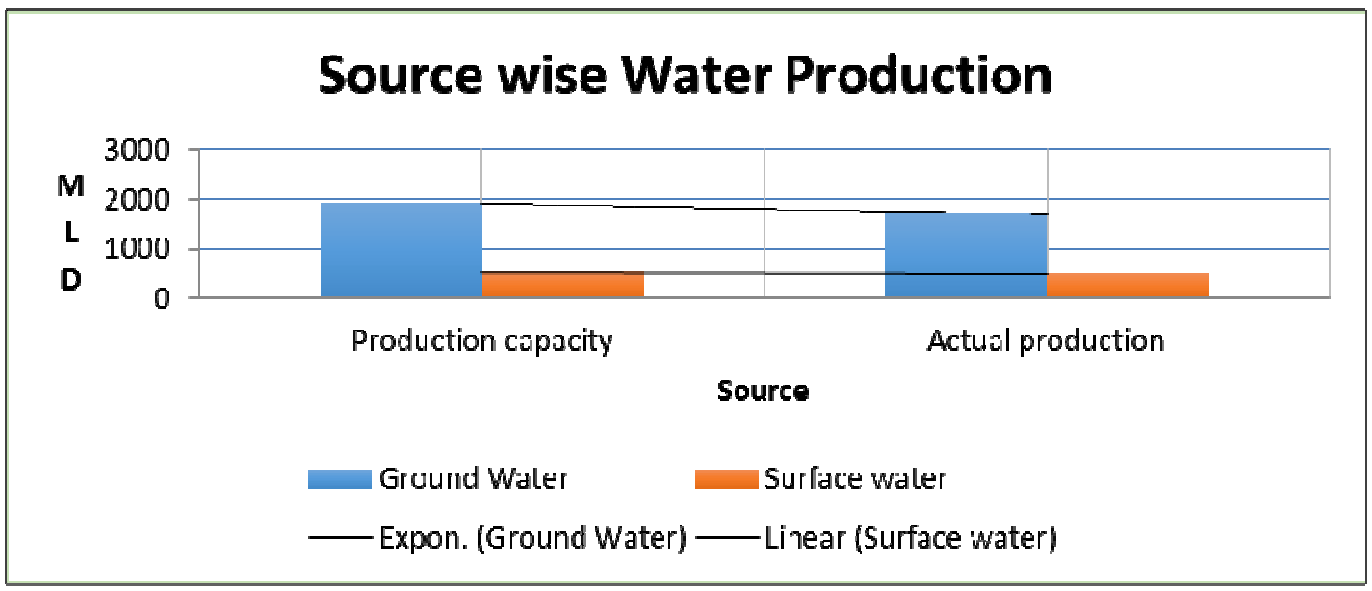

Figure 2. Water Production and Sources ${ }^{6}$.

In global concept, ground water provides drinking water for more than $97 \%$ of the rural population who do not have access to public water-supply systems. Even some major cities of USA, such as San Antonio, Texas rely solely on ground water for all their needs. Withdrawals of ground water are expected to rise in the coming century as the population increases and available sites for surface reservoirs become more limited ${ }^{17}$.

\section{SAMPLING DESIGN AND COLLECTING DATA}

Usually an account is to be opened against every single connection and it should be done simultaneously. It is the convention and regulation of DWASA. Recording the used water accordingly and billing the same are very important takes for reducing system loss and increasing the revenues. If the competent authority does not issue bills, then used water remains unrecorded. In the fiscal year 2002-2003, 10253 numbers in 2003-2004, 10613 numbers and 2004-2005, 6232 number of consumers have had water connections. Nevertheless, their accounts were not opened while issuing the CP. Therefore, they were totally remained untouched with the billing system. Whereas all of them consumers were using water after having the connections. Though they were using water but not recorded at all and billing was not possible against these connections. This is one of the main causes of non-revenue water that contributes undersigned system loss [Table 1].
Table 1. Targeted, published \& actual system loss

\begin{tabular}{|c|c|c|c|c|}
\hline FY & $\begin{array}{c}\text { Target } \\
\text { set by } \\
\text { govt. (\%) }\end{array}$ & $\begin{array}{c}\text { Published } \\
\text { by } \\
\text { DWASA } \\
\text { (\%) }\end{array}$ & $\begin{array}{c}\text { Actual } \\
\text { System } \\
\text { Loss (\%) }\end{array}$ & $\begin{array}{c}\text { Amt. of } \\
\text { Revenue } \\
\text { Lost (Cr. } \\
\text { Tk.) }\end{array}$ \\
\hline $2002-03$ & 37 & 41 & 50.49 & 27.65 \\
\hline $2003-04$ & 36 & 54.25 & 55.54 & 49.02 \\
\hline $2004-05$ & 36.68 & 49.32 & 49.86 & 36.13 \\
\hline
\end{tabular}

The information available in the above table sorted it out the gap among three captions. This is really an excessive change at the revenue collections. In 2002-2003 actual system loss was 50\% but published data was only $41 \%$. That's why DWASA lost a huge amount of revenues. DWASA exceeded the maximum system loss limit which was set by the government. This high magnitude system loss contributed significant loss of revenues [Table 2 and Table 3]..

Table 2. Scenario of System Losses

\begin{tabular}{|c|c|c|c|}
\hline FY & $\begin{array}{c}\text { Total } \\
\text { System } \\
\text { Loss }\end{array}$ & $\begin{array}{c}\text { Technical } \\
\text { Loss }\end{array}$ & $\begin{array}{c}\text { Non-Technical } \\
\text { Loss }\end{array}$ \\
\hline $2002-2003$ & 50.49 & 20 & 30.49 \\
\hline $2003-2004$ & 55.54 & 20 & 35.54 \\
\hline $2004-2005$ & 49.86 & 20 & 29.86 \\
\hline
\end{tabular}


Table 3. Lease Zone Wise System Loss (2003-2004).

\begin{tabular}{|c|c|c|c|c|}
\hline $\begin{array}{c}\text { Name of } \\
\text { Zone }\end{array}$ & $\begin{array}{c}\text { Out/ } \\
\text { Non-lease } \\
\text { out }\end{array}$ & $\begin{array}{c}\text { System } \\
\text { loss set } \\
\text { by } \\
\text { Govt. } \\
(\%)\end{array}$ & $\begin{array}{c}\text { Actual } \\
\text { System } \\
\text { Loss }\end{array}$ & Remarks \\
\hline Z-1 & $\begin{array}{c}\text { Non lease } \\
\text { out }\end{array}$ & 36.68 & 65 & \\
\hline Z-2 & $\begin{array}{c}\text { Non Lease } \\
\text { out }\end{array}$ & 36.68 & 77 & \\
\hline Z-3 & Lease out & 36.68 & 42 & \\
\hline Z-4 & Lease out & 36.68 & 48 & \\
\hline Z-5 & Lease out & 36.68 & 36 & lease out \\
\hline Z-6 & Lease out & 36.68 & 55 & zone \\
\hline N.Gonj) & $\begin{array}{c}\text { Non-lease } \\
\text { out }\end{array}$ & 36.68 & 65 & \\
\hline
\end{tabular}

It is observed that in FY 2003-2004 system loss of PPI revenue Zone-5 is $36 \%$. This was less than other zones and somewhere lower than the maximum limit set by the Govt. This lease out zone was administered and directed by Cooperative Association of Dhaka WASA. All the directors and their fellows of this association were the employees of DWASA and they did their job successfully for operating PPI zone. They are capable enough to reduce the system loss. Therefore when these employees were under the administration of DWASA they could not able to optimize the targeted system loss like PPI zone. This phenomenon is deplorable and not acceptable to general mass as well as to the nation [Table 4).

\section{System Loss}

At the end of the month, tariff of water is receiving through billings. But it is seen that billing is inconsistent to the production as well as distribution. It means that billed water is lower than the produced water. Therefore, difference in between production and billing is called system loss [Fig 3].

System Loss $=\frac{\text { Water Proluced-Water Sold }}{\text { Water Produced }} \times 100$

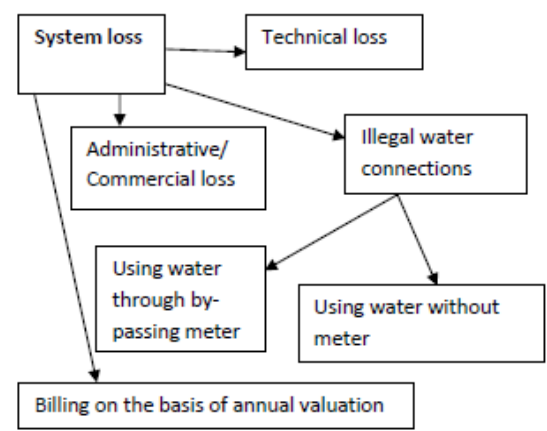

Figure 3: Classification of System Loss

Table 4. System Loss (NRW) for Global Cities ${ }^{15}$

\begin{tabular}{|l|l|l|l|}
\hline Sl. No. & Name of cities & $\begin{array}{l}\text { Avg. } \\
\text { System } \\
\text { Loss (\%) }\end{array}$ & \\
\hline 1. & $\begin{array}{l}\text { England and } \\
\text { Wales }\end{array}$ & $19 \%$ & \\
\hline 2. & Bangkok & $25 \%$ & \\
\hline 3. & Amman & $34 \%$ & \\
\hline 4. & Lagos & $99 \%$ & highest \\
\hline 5. & Mexico & $51 \%$ & \\
\hline 6. & Eastern & $11 \%$ & \\
\hline 7. & Manila & & Lowest \\
\hline 8. & Singapore & $5 \%$ & \\
\hline
\end{tabular}

\section{SERVICE CONNECTIONS}

Every domestic holding number will consider for a service connection with a prescribed tested meter. Utility organization will ensure billings for service connections based on actual meter readings, disordered meter could be replaced by good one and stopped average billing, every six months interval working area of Revenue Inspector shall be changed, The taskforce and higher authority shall check at least $10 \%$ readings (collected by inspectors) physically, mark the consumers using water through illegal or by pass connection and regular the same immediately and press them under lawful action for their illegal activity \& accountability must be high at all levels, water services must be adequately priced, these information should be reliable on production and consumption, NRW program must be institutionalized. NRW must be consistent and an enabling environment must be created. Utility services must have autonomy in terms of management and they need competent and motivated 
employees. Tariffs should be adequate in terms of cost and benefit to reduce NRW. Meter chamber should construct in a visible place to read out easily [Table 5].

Table 5: Achievement through year round program at Dhaka WASA [7].

\begin{tabular}{|c|c|c|c|c|}
\hline $\mathrm{Sl}$ & Subject Area & $\begin{array}{l}\text { Year } \\
2008\end{array}$ & $\begin{array}{l}\text { Bench } \\
\text { Mark }\end{array}$ & $\begin{array}{l}\text { Year } \\
2013\end{array}$ \\
\hline 1. & NRW\% & 40.38 & 25 & 26.66 \\
\hline 2. & $\begin{array}{ll}\text { Bills sent } \\
\text { out } \%\end{array}$ & 93.00 & 99.5 & 99.00 \\
\hline 3. & $\begin{array}{l}\text { Revenue } \\
\text { Collection \% }\end{array}$ & 64.50 & 95.00 & 95.00 \\
\hline 4. & $\begin{array}{l}\text { Manpower/ } \\
1000 \\
\text { connections }\end{array}$ & 16.20 & 12.00 & 9.16 \\
\hline 5. & $\begin{array}{l}\text { Operating } \\
\text { ratio }\end{array}$ & 0.90 & .65 & .66 \\
\hline
\end{tabular}

\section{SOCIO ECONOMIC ASPECTS}

Everyone should explore the escape route from alignment of system loss. Technical approaches to combating NRW have met with limited success. Usually utility staff only appeared when called out in an emergency or a crisis, rather than show a daily presence in a locality. Caretaker approach would add a social dimension to addressing the problem.

\section{ANALYSIS OF WATER TREATMENT DATA:}

System losses are usually being caused through leaking and burst pipes, illegal connections and metering inaccuracies [Table 6). It is heightened due to a rapidly growing and urbanized global population and the impacts of climate change which together lead on scarce water resources. Overall, the right configurations of technological, institutional and financial mechanisms require being adapted to meet local circumstances ${ }^{9}$.
Table 6: Causes of failure of NRW

\begin{tabular}{|l|l|l|}
\hline S1 no. & $\begin{array}{l}\text { Parameters or Reasons of } \\
\text { failure }\end{array}$ & $\begin{array}{l}\text { Proba } \\
\text { bilitie } \\
\text { s (\%) }\end{array}$ \\
\hline $1^{\text {st }}$ Failure & $\begin{array}{l}\text { Poor design and planning } \\
\text { scope }\end{array}$ & 15 \\
\hline $2^{\text {nd }}$ Failure & $\begin{array}{l}\text { Applications of preconception } \\
\text { but not experimentation }\end{array}$ & 20 \\
\hline $3^{\text {rd }}$ Failure & $\begin{array}{l}\text { Partial implementation or } \\
\text { incomplete project }\end{array}$ & 12 \\
\hline $4^{\text {th }}$ Failure & $\begin{array}{l}\text { Lack of mobilization of skill } \\
\text { human resources and financial } \\
\text { services }\end{array}$ & 18 \\
\hline $7^{\text {th }}$ Failure & $\begin{array}{l}\text { Failure of coordination among } \\
\text { components of program }\end{array}$ & 10 \\
\hline $5^{\text {th }}$ Failure & $\begin{array}{l}\text { Under estimation of weight of } \\
\text { the difficulties }\end{array}$ & 11 \\
\hline & Failure & 14 \\
\hline
\end{tabular}

NRW contains physical losses (pipe leaks, loss of pressure) and commercial losses (illegal connections, unbilled metered water, unmetered public use, meter error, unauthorized used and water for which payment is not collected or not estimated). NRW levels are so high in many under developed and so called developing countries, and they can be expensive to reduce or control the causes of failure [Fig 4]. 
NRW INCREASING PARAMETERS (CAUSES OF FAILURE)

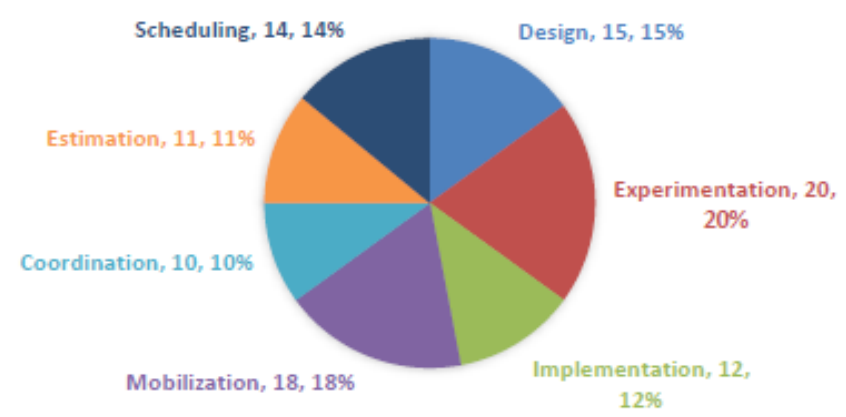

Design

Experimentation

E Implementation

Mobilization

coordination

Estimation

- scheduling

Figure 4. Causes of Failure of NRW ${ }^{15}$.

\section{Water Tariff (non-metered)}

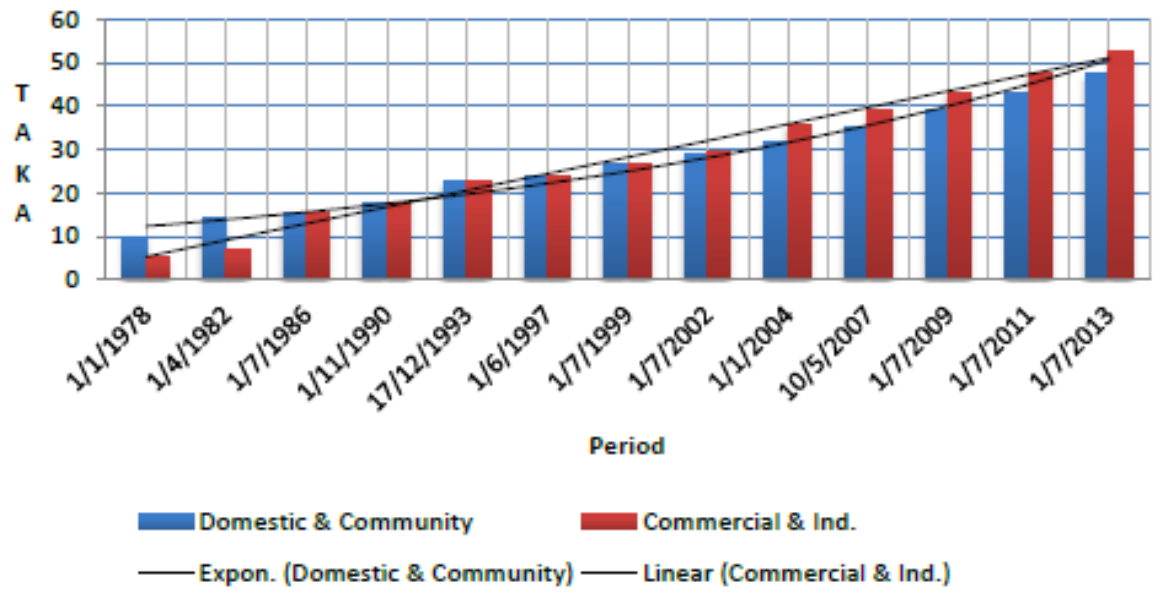

Figure 5. Domestic vs. Commercial tariff at Dhaka WASA ${ }^{6}$.

NRW identifies: Unbilled water with respect to a) local and system performances of pressure and flow, b) non-revenue and illegitimate water consumption, and c) locations and quantity of water breaks and water losses. The results of this development is to enable both utilities and consumers to proactively manage their water usage and achieve higher levels of sustainability in water supply $\left.{ }^{16}\right]$. Domestic and commercial rating have significant differences duration and impose of water tariff [Fig 5]

\section{CONCLUSIONS}

Dhaka WASA is one of the major utility service for city dwellers. The reputation and economic stability of this organization is fully depended on qualities of services. Collecting revenue from the sale of available water and rendering sewerage service are only the sources of revenues. NRW contributes system loss, which is ultimately shortening the revenue. To solve NRW problem: governance and tariffs must be tackled first, leak detection equipment comes last nor first, repair visible leaks, make utility staffs responsibility for small zones, meter all production and consumption properly, add strict metering, provide incentives for utilities staffs for performance.

\section{RECOMMENDATIONS}

For reducing system loss at DWASA, a high power taskforce shall be reformed headed by maintenance $\&$ operation director and supported by finance director. This task force shall work independently: enumerate irregularities, find out illegal connections and by pass or extended connections. The taskforce shall give recommendations for justified punishment against the person(s) and employee (s) (if any) those who involve such crimes or irregularities: ensure availability of quality water meter, introduce electronic digital water meter by providing non-return valve and hour run meter associates with all other common accessories, find out leakage and repair immediately, rehabilitate old and worn out distribution lines, non-metered connections 
shall be metered immediately, ensure meter sealing to protect meter tempering.

\section{REFERENCES}

1. Arthur C. McIntosh (2003), Asian Water Supplies Reaching the Urban Poor Published by Asian Development Bank, Co-published by IWA Publishing, Aliance House, 12 Caxton Street, London, UK.

2. C R Kothari (2000), Business Research Methodology, Methods and Techniques, 2nd edition, Wisha

3. Prakashani, New Delhi, India.

4. IWM (2005), Resource Assessment and Monitoring of water supply sources for Dhaka City Preliminary Assessment Report, Dhaka, Bangladesh

5. Asian Development Bank (2006), Mid Term Report of Dhaka Water Supply Project- TA 4651 BAN: DWASA.

6. BUET (2000), Updating and existing ground water and land subsidence project, Final Report, Vol-1, Department of Water Resources Engineering and Institute of Flood Control and Drainage Research, BUET, Dhaka, Bangladesh.

7.MIS report of Dhaka WASA, June, 2014.

8. http://www.dwasa.org.bd/

9.http://www.iwahq.org/1ny/themes/managing-utilities /utility-efficiency/non-revenue-water.html

10.Malcolm Farley, Gary Wyeth, Zainuddin Bin Md. Ghazali, Arie Islander and Sher Singh (2008)-The Manager's Non Revenue Water Hand Book-A guide to understanding water loss- USAID contract 486-C-00-05-0000-00.

11. SISS Water supply and sanitation in Chile Efficiency (water losses).

12. OFWAT. 2008. Water industry facts and figures

13. American Water Works Association, M36 Publication, 3rd Edition, [2] Water Audits and Loss Control Programs, 2009

14. Richard G. Sykes, Andrew K. Enos and Ronald L. Bianchetti, East Bay Municipal Utility District, Oakland, California, USA: Monitoring and Managing Unaccounted for Water, Proceedings of the International Symposium on Efficient Water Use in Urban Areas - Innovative Ways of Finding Water for Cities, 8 to 10 June 1999, quoted on the website of UNEP's International Environmental Technology Centre (IETC)
15. https://en.wikipedia.org/wiki/Non-revenue_water 16. Dan Koo, John, Kalayn, 2015, Towards Sustainable Water Supply: Schematic Development of Big Data Collection Using Internet of Things (Lot), Indiana University, USA.

17.http://www.freedrinkingwater.com/water_quality/q uality $2 / j$-1-08-differences-ground-n-surface-water-qua lity.htm 